Table 1. Mental Health Act category of Guardianship cases in England \& Wales on 31 March 1998

original papers

\begin{tabular}{lc} 
Mental disorder (Mental Health Act category) & $n(\%)$ \\
\hline Mental illness & $474(67)$ \\
Mental impairment & $119(17)$ \\
Severe mental impairment & $35(5)$ \\
Psychopathic disorder & $17(3)$ \\
Not recorded & $45(7)$ \\
Total & 690
\end{tabular}

two enumeration dates, there were 428 new Guardianship cases, 309 discharged cases and 103 cases taken on and discharged from Guardianship.

Two hundred and ninety-seven patients (43\%) were aged under 50 and 157 (26\%) were aged over 75 on 31 March 1998. The category of mental disorder is shown in Table 1.

The source of the order was by application in 650 (94\%); the remainder were made by courts. There was a requirement to reside in $443(64 \%)$ cases, to attend in $182(26 \%)$, and for access in $177(26 \%)$.

Two hundred and thirty (50\%) of those in the 'mental illness' legal category were identified as having serious mental illness (either psychosis or major affective disorder). Only 59 cases (12\%) were patients aged over 65 years with organic psychiatric disorders, including dementia and 154 had mental impairment/severe mental impairment.

\section{Comment}

The national study has identified that Guardianship is generally not widely used. There is, however, marked variation in use with some authorities being more proactive. The category of mental disorder was mental illness in two-thirds of cases, but few of these were elderly patients with organic psychiatric disorder. Indeed in a third of cases the order was used for patients with severe mental illness and a level of 'short-term' use was also identified.

The reasons for variation in the use of the order and further exploration of the outcome and satisfaction with the use of Guardianship is being explored in the second phase of this current study. Additionally, we are canvassing clinicians' views as to whether the powers available under the current Mental Health Act are sufficient to manage all groups of people in the community or whether a community treatment order is also required.

\section{References}

BARRY, N. (1987) The great Guardianship debate. Social Work Today, $\mathbf{1 8}, 9$

BEDI, B. (1985) Coping with power Social WorkToday, 10, 16-19.

BLOM-COOPER, L., HALLY, H. \& MURPHY, E. (1995) The Falling Shadow: One Patient's Mental Health Care 19781993. London: Duckworths.

BLUGLASS, R. (1984) Compulsory

power in the community -

Guardianship. In Guide to the Mental Health Act. Edinburgh: Churchil Livingstone.

CAMPBELL, E. S. (1967) Report of the Royal Commission on the Law Relating to Mental Illness and Mental Deficiency 1954-1957(Percy Commission). Cmnd 169. London: HMSO.

*Jenny Shaw Senior Lecturer in Forensic Psychiatry, University of Manchester, Langdale Unit, Guild Park, Whittingham, Preston PR3 2JH B Barbara Hatfield Director of Mental Health Social Work Research Unit, Sherrill Evans Research Fellow, University of Manchester, Manchester
CRAIG, A. (1988) Guardianship survey. Social Services Research, 4, 39-42.

GRANT,W. (1992) Guardianship Orders: a review of their use under the 1983 Mental Health Act. Medical Science Law, 32, 19-324.

GUNN M. (1986) Mental Health Act Guardianship - where now? Journal of Social Welfare Law, 2, 144-152.

RITCHIE, J. H., DICK, D. \& LINGHAM, R. (1994) The Report of the Inquiry into the Care and Treatment of Christopher Clunis. London: HMSO.

, et al (1990) Use of Guardianship under the 1983 Mental Health Act. Medicine, Science \& Law, $\mathbf{3 0}$,

313-316.

NORMA KEARNEY AND ADRIAN TRELOAR

\title{
In the light of Bournewood
}

\section{Changes in the management of elderly incapacitated patients}

\section{AIMS AND METHOD \\ A postal audit of practice in the South-East Thames Region of England before and after the Bournewood judgements.}

\section{RESULTS}

There was a trebling in the rate of admission under section of elderly incapacitated patients occurred prior to the House of Lords' ruling. By the time of the ruling many consultants had not changed their practice. There is now, however, no impact of the ruling upon clinical practice. The majority of consultants remain concerned about the lack of safeguards for mentally incapacitated elders at the present time. 


\begin{tabular}{|c|c|c|c|}
\hline & Most favoured judgement & $\begin{array}{l}\text { Court of appeal } \\
n=3(12 \%)\end{array}$ & $\begin{array}{l}\text { Lords judgement } \\
n=22(88 \%)\end{array}$ \\
\hline $\begin{array}{l}\text { Did your rate of sectioning increase after the } \\
\text { Court of Appeal judgement? }\end{array}$ & Decreased, $n=1(4 \%)$ & Stayed same, $n=11(42 \%)$ & Increased, $n=14(54 \%)$ \\
\hline $\begin{array}{l}\text { Since the House of Lords' ruling, what has } \\
\text { happened to your rate of compulsory } \\
\text { admission of patients with dementia? }\end{array}$ & Decreased, $n=16(62 \%)$ & Stayed the same, $n=9(35 \%)$ & Increased, $n=1(4 \%)$ \\
\hline $\begin{array}{l}\text { Do you now section more patients with } \\
\text { dementia than you did before the Court } \\
\text { of Appeal judgement? }\end{array}$ & Yes, $n=6(23 \%)$ & No, $n=20(77 \%)$ & \\
\hline $\begin{array}{l}\text { Do you think that it is satisfactory that } \\
\text { patients without capacity are managed } \\
\text { without any statutory safeguards? }\end{array}$ & Yes, $n=7(27 \%)$ & No, $n=19(73 \%)$ & \\
\hline $\begin{array}{l}\text { Has the Bournewood case had an impact } \\
\text { for your future psychiatric practice? }\end{array}$ & Yes, $n=11(44 \%)$ & No, $n=14(56 \%)$ & \\
\hline
\end{tabular}

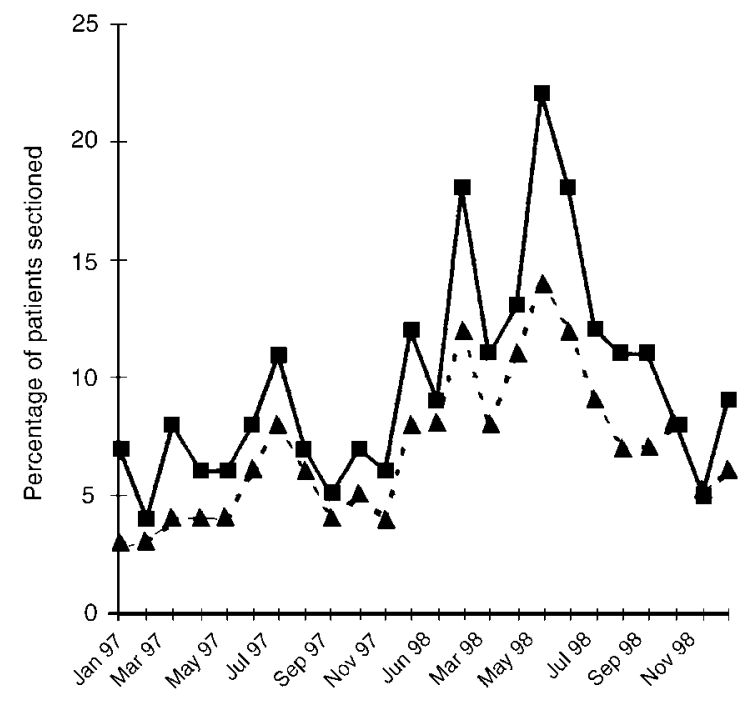

Fig. 1. Impact of Bournewood case on proportion of patients over the age of 65 years admitted under section, -1 , percentage of patients admitted under section; $\mathbf{-}-$, total percentage of patients under section.

When the Court of Appeal (COA) held that L. had been detained unlawfully the interpretation of the Mental Health Act changed dramatically (Department of Health, 1998). The informal admission of mentally incapacitated patients to mental hospitals became unlawful and with it a huge increase in the rate of sectioning became inevitable. Before the full effects of this had been seen, the House of Lords overturned the judgement. The grounds upon which the Law Lords overturned the judgement were principally that the Mental Health Act had been written with a libertarian intention and that the automatic detention of anyone with mental incapacity was not intended by the Act. Lord Goff (House of Lords, 1998) reminded us of the Percy Commission report (Royal Commission, 1957) which recommended "the offer of care, without deprivation of liberty, to all who need it and are not unwilling to receive it". Lord Goff pointed out that the Court of Appeal's judgement suggested that "there will be an additional 22000 patients detained on any one day, plus an additional 48000 admissions per year under the Act". This compared with a figure of 11000 detained under the Act at any one time prior to the COA judgement. It was also pointed out by Lord Goff that if the COA judgement were considered to apply to mental nursing homes not registered to receive detained patients, the estimates would be much higher. Lord Goff believed that L's readmission "did not constitute a deprivation of his liberty". Rather care was provided to a patient whose illness had deprived him of the ability to choose under the doctrine of necessity.

Although the judgement was unanimously overturned, Lord Steyn (House of Lords, 1998) believed that the result was "an indefensible gap in our mental health law". He said "the general effect of the decision of the House of Lords is to leave the compliant incapacitated patients without the safeguards enshrined in the Act of 1983" and lamented the fact that "the common law principle of necessity contains none of the safeguards of the Act of 1983". He concluded by asserting that "there is no reason to withhold the specific and effective protections of the Act of 1983 from a large class of vulnerable mentally incapacitated adults. Some opinion at the time of the Lords ruling suggested, that the issue of mental capacity had come to stay, and that changes in practice which resulted from the COA judgement would be permanent and consolidate further (Eastman, 1998).

The UK government (Department of Health, 1998) issued guidelines after the House of Lords' ruling advising informal admission of compliant incapacitated patients but suggesting regular assessment of capacity during admission, consultation with relatives and/or carers, and visits by hospital managers or advocates if no-one from outside the hospital would otherwise take a continuing interest in their care.

The revised edition of the Mental Health Act Code of Practice (Department of Health \& Welsh Office, 1999) has since been published and advises the informal admission of the mentally incapacitated and their treatment under the common law doctrine of necessity. Reference is made to consultation with immediate relatives and carers, but no other formal safeguards are recommended. 


\section{The study}

We undertook a postal survey of consultant old age psychiatrists practising in the former South-East Thames original papers NHS Region and also collected data on rates of detention from Mental Health Act managers in the same region. Census data on admissions of patients over the age of 65 years as well as patients detained at any one time were collected.

\section{Findings}

Twenty-six (72\%) replies out of 36 questionnaires sent out were received from consultants. Responses to questions are shown in Table 1. Administrator's responses were available from seven hospitals and covered a total of 410 beds available for the assessment of the elderly. Figure 1 shows the percentage of all admissions under section on a month by month basis as well as cumulative data on the number of patients remaining detained. It should be noted that these changes appear to reflect alterations in the practice of some, but not all consultants.

\section{Discussion}

Over half of the consultants felt that their practice had changed as a result of the Bournewood judgement, but only a minority felt that the judgement still affected their practice. The majority of consultants agreed with Lord Steyn that the absence of safeguards for this group was not satisfactory. The data collected via Mental Health Act administrators show that the rate of detention was slow to increase following the COA judgement and this fits with the need to plan implementation of the COA judgement and the working groups which were established to do this at local level. By the time of the Lords ruling, the rise in detentions showed no sign of plateauing and it seems likely that detentions would have risen further had the judgement not been overturned.

Following the House of Lords judgement the detention rate appears to have returned to the pattern that pertained prior to the COA judgement. This suggests that the impact of the Bournewood case is now minimal and that the predicted permanent change in psychiatric care of the mentally incapacitated (Eastman, 1998) has not occurred. Even though around half the responding consultants felt that the judgement had had an impact upon their practice, there is no evidence of a continuing impact from the Bournewood judgement on clinical practice.

Although the Mental Health Act may not provide an ideal framework for the safeguarding of the mentally incapacitated, the effective absence of safeguards must, however, remain as concerning now as it was, last year, to Lord Steyn. At the present time in the UK, legislation is being considered that will change the management of the mentally incapacitated. A proposed revision of the Mental Health Act is considering the use of capacity as the key basis for detention, and the Government's proposals on mental incapacity have suggested the establishment of formal proxies for decision-making (Lord Chancellors Department, 1997).

Over two-thirds of responding consultants agree that the lack of safeguards is a problem. There is a risk, however, that if new processes were cumbersome, they might effectively obstruct the delivery of health care to the incapacitated. In our view the challenge now is to establish those safeguards in a way that is both effective as well as an efficient use of resources.

\section{References}

DEPARTMENT OFHEALTH (1998) Health HOUSE OF LORDS (1998) R. v. Service Circular; L. v. Bournewood Community and Mental HealthTrust, decision by the House of Lords in the Appeal. HSC 1998/122. London: Department of Health

— \& WELSH OFFICE (1999) Mental Health Act Code of Practice. London: The Stationery Office.

EASTMAN, N. (1998) Bournewood: an indefensible gap in mental health law. British Medical Journal, 317, 94-95. Bournewood Community Mental Health NHS Trust ex part L. (by his next friend). House of Lords Judgement, 25th June 1998.

LORD CHANCELLOR'S DEPARTMENT (1997) Who decides? Making Decisions on Behalf of Mentally Incapacitated Adults. London: The Stationery Office. ROYAL COMMISSION (1957) Royal Commission on the Law Relating to Mental Illness and Mental Deficiency, 1954-1957. London: HMSO.
Norma Kearney Specialist Registrar in Old Age Psychiatry, Guy's, King's and St Thomas's Medical School and Oxleas NHS Trust, Upton Day Hospital, 14 Upton Road, Kent DA6 8LQ, *AdrianTreloar Consultant and Senior Lecturer in Old Age Psychiatry, Guy's, King's and StThomas's Medical School and Oxleas NHS Trust, Room 19, Memorial Hospital, Shooters Hill, London SE18 3RZ

Psychiatric Bulletin (2000), 24, 54-56

\title{
PETER GREENGROSS, DORIS HOLLANDER AND RICHARD STANTON
}

\section{Pressure on adult acute psychiatric beds}

\author{
Results of a national questionnaire survey
}

\section{AIMS AND METHOD}

To quantify perceived problems with psychiatric bed availability nationally using a questionnaire survey of all 210 UK mental health trusts.

\section{RESULTS}

One hundred and seventy-three $(82 \%)$ trusts replied. Thirty (17\%) are often over-occupied, 21 (15\%) often have problems with bed availability. Ten ( $7 \%$ ) often use extra-contractual referrals (ECRs). Frequent over-occupancy is associated with deprivation. Frequent use of ECRs is associated with relatively few beds.

\section{CLINICAL IMPLICATIONS}

Problems with bed availability are found nationwide, but outside southern England are relatively infrequent. Such problems are less pronounced than in Greater London. 